\title{
O culto aos mitos sobre as altas habilidades/superdotação?
}

\author{
The cult to the myths about high abilities/giftedness?
}

\author{
Susana Graciela Pérez Barrera Pérez
}

Doutora em Educação pela Pontifícia Universidade Católica do Rio Grande do Sul (PUCRS), sócia fundadora e membro da Comissão Técnica do ConBraSD, membro do Conselho Técnico da AGAAHSD, da Ficomundyt e do Grupo de Pesquisa CNPq da UNIP "Inteligência e criação: práticas educativas para portadores de altas habilidades”, Porto Alegre, RS - Brasil, e-mail: susanapb@terra.com.br

\section{Resumo}

O tema das altas habilidades/superdotação e as pessoas que apresentam esse comportamento são há muito tempo objeto de mitos e crenças populares que fazem do tema um tabu e que invisibilizam essas pessoas. A ainda tímida produção científica brasileira e a crescente visibilidade que o tema vem adquirindo na educação brasileira, principalmente por força das normas educacionais mais recentes, que preveem o atendimento educacional especializado aos alunos com altas habilidades/superdotação em todos os níveis, etapas e modalidades da Educação, faz que aumente a procura por publicações estrangeiras, muitas vezes, elaboradas por pessoas que não possuem formação teórica ou experiência na área. O presente artigo faz uma análise crítica do livro francês $A$ cultura dos superdotados? (Bergès-Bounes \& Calmettes-Jean, 2010), com o objetivo de mostrar como os mitos e crenças populares sobre as pessoas com altas habilidades/ superdotação, compilados por Pérez (2003), recriados e reafirmados na publicação, podem conduzir à criação de uma imagem patologizada e deturpada desse ser humano diferente, negando-lhe, em última instância, o direito de construir uma identidade sadia.

Palavras-chave: Altas habilidades/superdotação. Mitos e crenças populares. Identidade.

\begin{abstract}
Since long time ago, high abilities/giftedness and people showing such behavior have been submitted to myths and popular beliefs, which turn this subject a taboo and make these persons invisible. The still scarce Brazilian scientific production and the growing visibility the subject is gaining within the Brazilian education, specially because of the most recent educational laws, which foresee specialized educational services for highly able/gifted students in all educational levels, stages and modalities, have increased the search for foreign publications, often written by people
\end{abstract}


who do not have proper theoretical education or experience on the field. This paper bring a critical analysis of the French book entitled La culture des surdoués? (Bergès-Bounes E Calmettes-Jean, 2010), aiming at showing how the myths and popular beliefs about highly able/gifted people, compiled by Pérez (2003), recreated and reassessed in the publication, could lead to create a pathologized and distorted image of these different human beings, ultimately denying them the right to build a healthy identity.

Keywords: High Abilities/Giftedness. Myths and popular beliefs. Identity.

\section{Introduçáo}

Há alguns anos fiz uma compilação dos mitos e crenças populares sobre as pessoas com altas habilidades/superdotação (PAH/SD), classificando-os em sete categorias (Pérez, 2003): os mitos sobre constituição, que especulam sobre possíveis origens das altas habilidades/superdotação (AH/SD) e características inatas a essas pessoas; os mitos sobre distribuição, que dão às $\mathrm{AH} / \mathrm{SD}$ distribuições específicas; os mitos sobre a identificaşão, que buscam omitir ou justificar a desnecessidade dessa identidade; os mitos sobre niveis ou graus de inteligência, decorrentes de equívocos sobre o conceito de inteligência; os mitos sobre desempenho, que transferem expectativas e responsabilidades descabidas e irreais às $\mathrm{PAH} /$ $\mathrm{SD}$; os mitos sobre consequências, que lhes atribuem características psicológicas ou de personalidade não vinculadas a seu comportamento, e os mitos sobre o atendimento, que muitas vezes resultam na precariedade na ou ausência de serviços públicos eficientes para essa população.

Não sabia eu que essa lista poderia ser ainda hoje válida, revisitada, recriada e até ampliada por profissionais que, teoricamente, deveriam ser mais imunes a essas crenças populares que refletem o imaginário simbólico elaborado para explicar situações ou pessoas que a lógica humana não consegue compreender.

Embora inicialmente tivesse em mente fazer uma resenha do livro $A$ cultura dos superdotados?, que Bergès-Bounes e Calmettes-Jean (2010) organizaram, a frutífera reconstituição de todos os mitos que especialistas e pesquisadores da área (brasileiros e do mundo inteiro) há muito tempo tentamos desconstruir obrigou-me a fazer uma análise mais detalhada, que permitisse alertar os educadores sobre os perigos que os mitos representam quando se trata de implantar o processo inclusivo nos bancos escolares.
Os autores do livro, em sua maioria, são profissionais da saúde (psicólogos e psiquiatras) vinculados a centros de atendimento psiquiátrico e de pesquisa de problemas cognitivo-intelectuais, que escrevem sobre os "problemas", "distúrbios", "sintomas", "disfuncionamentos", "inadaptações", "neuroses" e "psicoses" dos superdotados sob as perspectivas freudiana e lacaniana. Sabe-se que os profissionais da Educação, talvez por falta de valorização profissional, ainda não confiam na sua capacidade de identificar alunos com AH/SD e, por isso, essas áreas da saúde ainda têm uma descabida ascendência e influência no âmbito educacional.

A capa vermelha da edição brasileira do livro (CMC Editora), que mostra um rapaz com vestes de super-herói, com as mãos na cintura e uma máscara nos olhos, estufando o peito (no qual está escrito "QI") ao centro de algo que parece ser um universo, já estampa vários dos mitos sobre as $\mathrm{PAH} / \mathrm{SD}$. Para não deixar dúvidas, a palavra "superdotados" tem o prefixo "super" escrito em letras maiúsculas de maior tamanho. Essa ideia de que as PAH/SD são super-heróis, cujo QI determina uma superioridade, que não precisam de nada e são o centro do universo é um estereotipo bastante difundido na nossa sociedade e muito dificulta a identificação do ser humano real que está escondido por baixo dessa "máscara", sentado nos bancos escolares.

Apresentado como resultado de uma jornada de estudos realizada no hospital francês Saint-Anne, em 2002, na qual se questionou o que esconderia "a inflação atual do significante superdotado" (Bergès-Bounes \& Calmettes-Jean como citado em Bergès-Bounes \& Calmettes-Jean, 2010, p. 8), o objetivo do livro é mostrar "as tentativas de clínicos para restituir uma dinâmica a esse significante ditatorial" (Bergès-Bounes \& Calmettes-Jean como citado em Bergès-Bounes \& Calmettes-Jean, 2010, p. 10). Bergès-Bounes e Calmettes-Jean revelam o conceito de "superdotação" ou "precocidade intelectual", 
termos usados na França como sinônimos de AH/ $\mathrm{SD}$, que os autores aplicam quase exclusivamente a crianças:

a partir de uma estrita definição ligada aos resultados dos testes de eficiência intelectual, considera-se atualmente superdotada ou criança intelectualmente precoce aquela que apresente o 'perfil psicológico' ou a dissincronia caracterizada por um disfuncionamento secundário, evocador das noções de desarmonia evolutiva ou de distúrbios instrumentais (Bergès-Bounes \& Calmettes-Jean como citado em BergèsBounes \& Calmettes-Jean, 2010, p. 8).

Os mitos de constituição - que a criança com $\mathrm{AH} / \mathrm{SD}$ possui distúrbios emocionais e/ou sociais, que ela é produto de pais controladores e que teria, também, sucesso garantido no futuro - já reafirmados logo na apresentação são ricamente recriados, em alguns capítulos mais brilhantemente do que em outros.

É tarefa bastante difícil selecionar somente alguns dos mitos nas intrincadas letras desses profissionais, pela sua prolífera distribuição, mas me parece importante apontar a sua descontribuição para a Educação, cujos representantes podem querer ler esse livro.

É extremamente relevante identificar o lugar de onde o livro foi escrito, que é a Unidade de Psicopatologia da Criança e do Adolescente do Centro Hospitalar Saint-Anne, que, segundo as organizadoras, "recebeu majoritariamente crianças com dificuldade de aprendizagem" e, há dois anos, passou a receber "demandas de consultas para crianças supostas intelectualmente precoces" (Bergès-Bounes como citado em Bergès-Bounes \& Calmettes-Jean, 2010 , p. 54). Esse é o universo do qual foi tomada a maioria dos casos relatados: pacientes cujas famílias procuraram o serviço porque apresentavam alguma dificuldade na escola ou mesmo em casa.

\section{Crianças com altas habilidades/ superdotaçáo ou criança doente?}

Assim como em qualquer outra população, as crianças com AH/SD podem apresentar também distúrbios emocionais e psicológicos, patologias como o TDAH (Transtorno de Déficit de Atenção com Hiperatividade), deficiências (física, auditiva, visual), dificuldades de aprendizagem, desvios de conduta, transtornos de personalidade, etc. Entretanto, isso não é regra e, como em qualquer população, a grande maioria de crianças com AH/SD são sadias. Dessa forma, a generalização de "sintomas" ou "disfuncionamentos" próprios de uma minoria a toda uma população é considerada uma atitude pouco científica em qualquer pesquisador.

A pesquisa de dois anos para entender a demanda da criança superdotada e de sua família em uma consulta hospitalar, realizada por BergèsBounes e a Unidade de Psicopatologia da Criança e do Adolescente do hospital já mencionado, teve as seguintes questões norteadoras:

que revelaria então, esse termo "superdotado"? De que outro significante teria ele tomado o lugar, além de um efeito de moda? O que significaria essa súbita inflação da inteligência precipitada nessas expressões "superdotado", "intelectualmente precoce" ou "alta potencialidade", inflação do que seria a palavra-mestra das famílias como "objeto causa do desejo"? (Bergès-Bounes como citado em BergèsBounes \& Calmettes-Jean, 2010, p. 55).

A afirmação inicial de que "é dessas sessenta e nove crianças (dezoito meninas e cinquenta e um meninos) vindas para consultar no hospital porque a questão da precocidade se colocava, que iremos falar, e não das crianças superdotadas em geral' (Bergès-Bounes como citado em Bergès-Bounes \& Calmettes-Jean, 2010 , p. 55, grifo nosso) é frequentemente esquecida ao generalizar os "achados" a todas as crianças com $\mathrm{AH} / \mathrm{SD}$.

O processo metodológico que levou a determinar a ordem dos "problemas" que essas 69 crianças tinham na escola incluiu um encontro com os pais - "que não visa nem a uma anamnese dirigida nem a um questionário" (Bergès-Bounes como citado em Bergès-Bounes \& Calmettes-Jean, 2010, p. 60) -e uma entrevista livre com as crianças para investigar as demandas dos participantes; a aplicação da prova do WISC e do teste projetivo de Rorschach - "pois os problemas de 'imaturidade', de comportamento e a estrutura da personalidade são muitas vezes fontes de interrogação" (Bergès-Bounes como citado em Bergès-Bounes \& Calmettes-Jean, 2010, p. 60) - e um exame de escrita. 
Depois desse chamado processo de "identificação", constata-se que o "universo" dessa pesquisa ficou delimitado a 20 crianças com escores elevados no WISC (não necessariamente crianças com AH/ $\mathrm{SD})$, mas que, pela "definição" dessas psicólogas, eram "superdotadas":

"Um superdotado é o resultado de testes: QI igual ou superior a 130 no WISC" -, 29\% das crianças que consultaram no serviço por uma possível precocidade correspondem a isso (sete meninas e treze meninos); as outras são crianças brilhantes, animadas por uma grande curiosidade intelectual; algumas, raras, confirmaram-se em sua fragilidade e suas particularidades linguageiras, mais do lado da psicose (BergèsBounes como citado em Bergès-Bounes \& Calmettes-Jean, 2010, p. 62).

Como atribuir, então, características e comportamentos à criança "superdotada" a partir de um "universo" tão pequeno, de 20 crianças com escore igual ou superior a 130 no WISC que consultaram um centro de atendimento psicopatológico porque apresentavam dificuldades de aprendizagem? É possível generalizar características e comportamentos em um período tão curto de tempo (dois anos), quando nenhum dos pesquisadores que há quase cem anos trabalham na área se atrevem a fazê-lo?

Será que o que é dito pelos pais ou o que "é escutado" de seus filhos pode caracterizar a criança $\operatorname{com} \mathrm{AH} / \mathrm{SD}$, visto que as autoras afirmam ter escolhido se centrar na "demanda dessas famílias e de suas crianças presumidas intelectualmente precoces" (Bergès-Bounes como citado em Bergès-Bounes \& Calmettes-Jean, 2010, p. 56)?

Forget (como citado em Bergès-Bounes \& Calmettes-Jean, 2010, p. 77), por exemplo, menciona muito en passant uma família que alegava que seu filho era "superdotado e precoce e tinha uma enurese primária persistente" e, por isso, atribui à criança com AH/SD

[...] a emergência de perturbações de funções do corpo, de fracassos nessas funções ou mesmo na eficiência escolar. As perturbações funcionais estão ligadas à erotização inapropriada e revestem uma função do corpo. O corpo se mostra assim portador da dimensão sexual, eludido e desconectado da fala e da demanda. São a enurese, os transtornos na higiene, os maus jeitos, inabilidade, etc. Essas manifestações são prejudiciais e pejorativas para o sujeito dito precoce (Forget como citado em Bergès-Bounes \& Calmettes-Jean, 2010, p. 82).

Atribui, então, às $\mathrm{AH} / \mathrm{SD}$ uma condição patológica: "nós podemos, de preferência, ver na manifestação sintomática que apresentam as crianças superdotadas ou precoces o testemunho da elisão, pela economia de nosso mundo, da consistência do objeto inapreensível que governa o desejo" (Forget como citado em Bergès-Bounes \& Calmettes-Jean, 2010, p. 83).

Cacciali (como citado em Bergès-Bounes \& Calmettes-Jean, 2010) relata os sintomas e dificuldades de um jovem escritor psicótico, com deficiência física, que apresenta elevado escore nos testes de QI. Não fica claro, no texto da autora, se ela considera que esse adolescente apresenta $\mathrm{AH} / \mathrm{SD}$, mas a relação feita no último parágrafo com a dificuldade da "criança precoce" leva a acreditar que esses sintomas e dificuldades são atribuídos às crianças com AH/SD.

Lacôte associa as AH/SD à anorexia, aproveitando uma comunicação sobre esse último tema, publicada nos Anais de uma Jornada de Estudos da Associação Lacaniana Internacional. Para esclarecer a "precocidade", a autora refere: "retomarei alguns traços de casos que encontramos em nossa clínica cotidiana, em que a inteligência da letra no mais alto nível científico pôde se conjugar a essa sintomatologia limite que é a da anorexia" (Lacôte como citado em Bergès-Bounes \& Calmettes-Jean, 2010,p. 121). Sob a perspectiva lacaniana, relata a história de vida de uma moça anoréxica que, talvez por ser uma "cientista de alto nível", a autora supõe que seja superdotada e, embora afirme que não se podem tirar conclusões gerais desse caso singular que "está longe de ser único", estende a todas as crianças com AH/SD a presença de uma exigência de permanente performance que contribuiria para a patologia:

em suma, essa jovem, como tantas crianças da ciência, generaliza a função da letra [...] Escutamos muitas vezes, dessas crianças da ciência que alternam desde seus primeiros anos seus estudos e o esporte sem que lhes seja permitido o menor momento de tédio fecundo (Lacôte como citado em Bergès-Bounes \& Calmettes-Jean, 2010, p. 127-128). 
Fleige Fleig contam a história de um menino delinquente (e intelectualmente precoce ou superdotado, não esqueçamos a sinonímia em francês) do qual são relatadas todas as atitudes que o vinculam à delinquência como uma consequência direta de sua "precocidade", "não no sentido da inteligência escolar, mas na lei que organiza a vida pública” (Fleig $\&$ Fleig como citado em Bergès-Bounes \& CalmettesJean, 2010, p. 141). Referindo que a "história de sua infância se assemelha muito ao destino de numerosas crianças nascidas nos bairros periféricos de não importa qual cidade sul-americana" (Fleig \& Fleig como citado em Bergès-Bounes \& Calmettes-Jean, 2010, p. 139), os autores se fazem uma pergunta há muito tempo respondida pelos pesquisadores da área de $\mathrm{AH} / \mathrm{SD}$ :

nos países em que todas as crianças vão à escola, é certo que a questão dos superdotados aparece ligada à aprendizagem, mas será que podemos examinar também essa mesma questão referida a uma outra experiência, em um contexto fora do processo escolar de aprendizagem? (Fleig \& Fleig como citado em Bergès-Bounes \& Calmettes-Jean, 2010, p. 141).

Depois de fazer uma exaustiva análise semântica de palavras como "inteligência", "lei" e "queimar" (porque o menino queimou-se num incêndio) e como se as palavras fossem o sujeito, Fleig e Fleig (como citado em Bergès-Bounes \& Calmettes-Jean, 2010, p. 143) concluem que "o menino é morto porque sabia demais, esse excesso de saber foi o agente de sua morte". A relação direta entre $\mathrm{AH} / \mathrm{SD}$ é um mito sobre consequências frequentemente aventado.

Bernardeau e Ferron (como citado em Bergès-Bounes \& Calmettes-Jean, 2010, p. 144) relatam a 'história de um caso 'extra' ordinário, uma observação longa” de uma criança de 4 anos de idade, filho de um casal cuja "situação familiar não é, claro, realmente simples". Essa criança que agride os colegas e os professores, razão pela qual já mudara duas vezes de escola (infantil) em três anos; já diagnosticada como hiperativa por um neurologista, embora "muito implicado e aplicado naquilo que faz" (Bernardeau \& Ferron como citado em Bergès-Bounes \& Calmettes-Jean, 2010,p. 153), e que a escola não aceitava matricular, era produto de uma gravidez gemelar cujo outro embrião a mãe perdera após um mês e meio, tendo conhecimento desse fato. No processo de avaliação psicológica, os autores constataram que o menino era "um superdotado bem escondido". Ao concluir o capítulo, os autores se perguntam: "a hiperatividade e o superinvestimento do pensamento são sintomas contra a angústia de morte e a depressão na mãe?” (Bernardeau \& Ferron como citado em Bergès-Bounes \& Calmettes-Jean, 2010, p. 153).

Pecarelo (como citado em Bergès-Bounes \& Calmettes-Jean, 2010, p. 154) relata o caso de um menino com "problemas de sono desde a primeira infância, uma angústia de separação, uma agitação e uma rivalidade fraterna com o irmão mais velho, que suportou muito mal a chegada do 'caçula', vivida como uma verdadeira 'intrusão"'. Explicando que "o perfil 'brilhante' do ponto de vista intelectual contrasta com a inquietude dessa criança", a autora parece entender que esse antagonismo é improvável em uma criança com AH/SD. Para ela, o hiperinvestimento intelectual é

uma via de apaziguamento de uma relação com o tempo mortífero, em que uma certa forma de saber desempenharia o papel de contraponto da perda, do luto, ensaio de facilitação de um lugar no seio da família, tentativa de suplência da labilidade identitária de um sujeito, e até mesmo das rivalidades fraternas (Pecarelo como citado em Bergès-Bounes \& Calmettes-Jean, 2010, p. 157).

Além dos casos patológicos relatados, há também dois ou três "casos" livrescos que reafirmam a ausência absoluta dos sujeitos que caracterizam as verdadeiras pesquisas que podem nos trazer alguma luz sobre as AH/SD.

Um deles é o capítulo de Cathelineau (como citado em Bergès-Bounes \& Calmettes-Jean, 2010, p. 87), que filosofa sobre Joyce e o sinthoma, hipotetizando que "o sujeito superdotado manifesta talvez uma dificuldade de enodamento", apelando à semelhança de traços significativos entre "a criança superdotada" e o escritorirlandês: o gosto pelo saber, uma dificuldade com seu próprio corpo, "a disposição para antecipar o saber daquele que é suposto transmitir-lhe", a não submissão e a subversão em seu proveito do que entende - "e parece fazê-lo por opção" (Cathelineau como citado em Bergès-Bounes \& Calmettes-Jean, 2010, p. 88). Diz o autor que “o 
gozo do pensamento vem suplementar um defeito ou uma falha de enodamento" (Cathelineau como citado em Bergès-Bounes \& Calmettes-Jean, 2010, p. 88), podendo ser um sinthoma. Afirma, em palavras leigas, que haveria uma dificuldade para integrar os três eixos: imaginário, subjetivo e real.

Em outro capítulo de uma página, o mesmo autor relaciona o livro $O$ doido e o professor, de Simon Winchester, que relata a história real de William Chester Minor, cirurgião do exército americano internado em um hospital psiquiátrico inglês que contribuiu com um dos autores do Oxford English Dictionary, enviando-lhe definições, etimologias e notícias, e que acabou decepando seu próprio sexo. Cathelineau (como citado em BergèsBounes \& Calmettes-Jean, 2010, p. 90) patologiza as $\mathrm{AH} / \mathrm{SD}$ dizendo que essa história não deixa de ter relação com "o caso de certos superdotados em que, curiosamente, a facilidade em relação ao simbólico assinala a psicose, mas pode dar lugar ao sintoma".

Ferron discorre sobre a vida de Pascal a partir de uma biografia escrita pela sua sobrinha, sobre a função do psicanalista, Lacan, Freud... e, ao fim, sobre a "dificuldade da criança precoce em se fazer objeto para enganar o Outro" (Ferron como citado em Bergès-Bounes \& Calmettes-Jean, 2010, p. 180).

Enfim, esses casos, dentre outros também patológicos, são os que orientam os autores em suas reflexões sobre "a criança superdotada", que, em geral, é objeto de uma inexplicável rejeição que, quem sabe, Freud poderia nos explicar.

Essa associação com a "doença" fica muito clara nas palavras de Calmettes-Jean (citado em Bergès-Bounes \& Calmettes-Jean, 2010, p. 63, grifo nosso), por exemplo, que manifesta a sua dificuldade de "encontrar um quadro nosográfico ${ }^{1}$ próprio para designar esse conjunto de crianças que apresentam clinicamente a particularidade de se sustentar por sua 'inteligência', por seu pensamento, por seu discurso"e afirma que "é forçoso constatar como uma etiologia ${ }^{2}$ prête-à-portertenta fazer um curto-circuito das questões oriundas de sintomatologias enigmáticas (Calmettes-Jean citado em Bergès-Bounes \& Calmettes-Jean, 2010, p. 63, grifo nosso).

\section{A criança com AH/SD e o número de ouro}

A associação constante das AH/SD aos escores de QI há muito tempo vem sendo questionada por diversos autores. Dentro da própria psicologia, não são poucos os autores que nos esclarecem quanto à ineficácia dessa associação, especialmente quando a avaliação está relacionada a áreas que não a linguística e a lógico-matemática.

Sternberg (1997, p. 47) afirma que "os testes de inteligência convencionais medem somente o aspecto analítico da inteligência" e nem sequer todo ele, e que eles não conseguem avaliar as habilidades criativas ou práticas. Também há evidências claras de que os escores dos testes de QI são altamente influenciados pela cultura, pelo ambiente, pelo próprio aplicador do teste, pelas condições de testagem e o grau de familiaridade com situações de teste e pelas diferenças raciais ou étnicas (Sternberg, 1997, 2008; Gardner, 2000; Gardner, Kornhaber \& Wake, 2003).

Sternberg, Grigorenko e Bundy (2001, p. 3) também alertam especialmente para o enraizamento cultural, social e ideológico dos testes de QI e advertem que, para prognosticar o desempenho, "esses testes não são suficientes por si mesmos e, se utilizados levianamente e fora de contexto, podem ser perigosamente enganadores".

Nãoé essa a visão com a qual concordam os autores, que questionam mais as possíveis imprecisões dos colegas que aplicam esses testes, chegando, inclusive, a propor um aumento do número para garantir a correspondência com o nome (superdotação).

Para Gregorius (como citado em BergèsBounes \& Calmettes-Jean, 2010, p. 202), as categorias das "crianças retardadas" às crianças superdotadas sempre se definiam em torno de uma noção de inteligência e, “já que a questão é de inteligência, a referência é o QI, quer dizer, uma norma, uma média estabelecida a partir da curva de Gauss". Diz a autora que a quantidade de vocábulos utilizados nos dias de hoje levam a uma classificação que perde credibilidade à medida que se torna mais complexa. Define, então, que "hoje em dia, esse termo [superdotado] simplesmente designa a criança de inteligência

\footnotetext{
Nosográfico: relativo à nosografia. Nosografia: tratado com descrição ou explicação das doenças.

Estudo das causas das doenças.
} 
superior" (Gregorius como citado em Bergès-Bounes \& Calmettes-Jean, 2010, p. 202).

O objetivo de Meljac (como citado em Bergès-Bounes \& Calmettes-Jean, 2010,p.13), no seu capítulo, é "precisar a definição de uma das noções postas em causa: o 'superdom', qualidade atribuída ao superdotado, chamado também de 'criança intelectualmente precoce' [EIP, em francês], ou dotada de um 'al to potencial' [pode-se acreditar estar falando de uma linha elétrica]”.

Para isso, ela comenta a variação das técnicas de padronização (que define como "prova de verdade" de um teste) na história da psicologia, passando pelas contribuições de Binet; "O QI do tipo Stern”, “o QI Wechsler", e sobre a facilidade de "produzir uma "criança brilhante" por meio de "manipulações" complementando:

Juntemos a essas manipulações - cometidas por operadores (não ouso dizer psicólogos) sem escrúpulos - o fato destes 'profissionais se encontrarem em geral em grupos ou associações trazendo em destaque as palavras 'brilhantismo', 'dons excepcionais', 'superdotados', 'crianças precoces' e outros termos narcisicamente lisonjeiros (Meljac como citado em Bergès-Bounes \& Calmettes-Jean, 2010, p. 20).

Perguntando-se se precocidade (superdotação) não seria mais um sinônimo de "bem (ou muito bem) 'classificado"' (nos testes, é claro), Meljac (como citado em Bergès-Bounes \& Calmettes-Jean, 2010, p. 22) sugere um limite mais exigente nesses instrumentos: fixar "o ponto de partida em três desvios padrão: QI = 145”.

Dentre as diversas relações estabelecidas entre a criança com AH/SD e o QI, encontramos o capítulo de Voyazoupoulos et al. É uma exceção quase que surpreendente, com alguns trechos inesperadamente bem ponderados, que alertam para "uma concepção redutora e ultrapassada da inteligência, considerada como unidimensional, estática e facilmente mensurável" e para "a falsa ideia de que esta 'inteligência' é única determinante nas dificuldades que uma criança pode apresentar em um momento de sua história" (Voyazoupoulos et al. como citado em Bergès-Bounes \& Calmettes-Jean, 2010, p. 50).

Sem abandonar a validade dos testes de QI, os autores refletem sobre os instrumentos de avaliação e sua grande variabilidade ocasionada por condicionantes externas e afirmam que a utilização da noção de QI por “certas mídias” e, às vezes, com a conivência de certos profissionais, fez "os testes expressarem algo muito diferente do que podem e muito mais do que lhes é permitido" (Voyazoupoulos et al. como citado em Bergès-Bounes \& CalmettesJean, 2010, p. 53).

\section{A criança com AH/SD: uma criança que não é perfeita?!}

Os mitos de perfeição, da origem divina das $\mathrm{AH} / \mathrm{SD}$, do aluno nota 10 e com desempenho equilibrado em todas as áreas, da associação com a genialidade, da "fabricação" da criança superdotada pelos seus pais e da prevalência do gênero masculino são encontrados ao longo das páginas do livro.

Meljiac (como citado em Bergès-Bounes \& Calmettes-Jean, 2010, p. 22) evoca “os 'gênios' pretensamente disléxicos", referindo que a escrita espelhada de "Leonardo da Vinci era de fato uma escrita codificada" e que "qualquer um pode consultar (porque foram publicados pelo New York Times) os boletins de notas de Einstein que sempre foi um excelente aluno e nunca se aborreceu, aparentemente, em aula".

Du Pasquier e Schnaidt encarregam-se de destrinchar, ao seu modo, uma frase bastante comum entre algumas crianças com AH/SD - "Meu cérebro vai mais rápido do que minha mão" - que Terrasier adjudica ao assincronismo. Entendem as autoras que essa "desarmonia", refletida na "incompetência" de uma "escrita desordenada, mal apresentada, suja e com aparência de rascunho, frequentemente difícil para ler ou ainda simplesmente muito lenta", mostra $\mathrm{o}$ avesso de "um excelente funcionamento cerebral", que é, "consequentemente, um funcionamento instrumental medíocre" (Du Pasquier \& Schnaidt como citado em Bergès-Bounes \& Calmettes-Jean, 2010, p. 33).

Felizmente, lembram de afirmar que não todas as crianças 'superdotadas' têm dificuldade para escrever, mas distorcem o seu perfeccionismo, que todos sabemos ser comum nelas, fazendo uma interpretação psicológica dele:

essas crianças nos confundem por suas contradições. Sua aspiração a uma perfeição não é mais que uma produção de um imaginário 
megalomaníaco forjado no domínio, na onipotência, que sustenta o temor de todo enfraquecimento (Du Pasquier \& Schnaidt como citado em Bergès-Bounes \& Calmettes-Jean, 2010, p. 36).

Segundo as autoras, o sofrimento corporal das crianças com $\mathrm{AH} / \mathrm{SD}$ quando escrevem deve ser interpretado como "uma tentativa de impedir a aparição de uma representação psíquica inconsciente" (Du Pasquier \& Schnaidt como citado em Bergès-Bounes \& Calmettes-Jean, 2010, p. 36) que a escrita demanda. Somente transcrevendo o trecho a seguir é possível demonstrar o fértil imaginário construído por Du Pasquier e Schnaidt para essas crianças "paradoxais":

com efeito, apesar do hiperinvestimento do intelecto e do saber, o sucesso escolar não está sempre à altura nessas crianças. [...] Em geral finas e sensiveis, elas podem também se mostrar imperativas, argumentadoras, rígidas em seu posicionamento até o ilógico o o incoerente. Apegadas e sedutoras, acontece-lhes entretanto, às vezes, de serem irritantes, buscando manter o domínio, maus jogadores, suportando mal as regras e os limites. Daí as relações dificiceis com os outros [...] Elas podem igualmente estar sujeitas a surpreendentes revoltas, inesperadas, excessivas, deslocadas, como se mostrar tranquilas e "sem problema", mas distraídas, pouco preocupadas com as contingências, a ponto de parecer desajeitadas, desordenadas. [...] com relativa frequência em sua história infantil ou atual manifestações com aparência psicossomática [...] se apresentam então como interiormente pouco estáveis, sem continuidade, sem eixo fixo, sujeitas a mudanças bruscas [...] nessas crianças, o Supereu fracassa em seu papel estruturante, pois sua psique se mantém organizada de maneira prevalente de um modo narcísico. [...] Muitas crianças têm de saída uma vaga consciência de sua doença ou de sua dor, um sofrimento que não pode ser dito devido às dificuldades reais em percebê-lo na confusão das vivências corporais, mas também devido às posturas de superioridade (Du Pasquier \& Schnaidt como citado em Bergès-Bounes \& Calmettes-Jean, 2010, pp. 38-39, grifo nosso).
De fato, essa imagem apresentada pelos diversos autores do livro encontra nesses trechos uma síntese generalizada - certamente não a partir de pesquisas amplas -, que delineia uma criança diabólica e insuportável, física e psicologicamente doentia, social e escolarmente incapaz, ilógica e incoerente (mas que parece ter conseguido enganar muito bem nos testes de QI), como fantasmagorizada pelo mitos de constituição (Pérez, 2003) e que não sempre tem sucesso, como prega a crença popular à qual as autoras aderem.

Numa linguagem bastante hermética para o público, Bergès associa o vocabulário rico e complexo de crianças com AH/SD e o interesse em temas próprios de pessoas mais velhas ou de adultos à reivindicação fálica que:

incide antes de tudo sobre o conhecimento e se manifesta pelo manejo do discurso, manejo que é um gozo estimulado pela questão dos adultos e mantida pela hipótese que, para esta questão, o adulto supõe que a criança pode não responder. É desse gozo que o superdotado testemunhará em seu sintoma (Bergès como citado em BergèsBounes \& Calmettes-Jean, 2010, p. 25).

Forget estimula no seu imaginário o mito da fabricação do filho superdotado por um pai ou uma mãe (ou ambos) que assim o desejam. O filho (superdotado), então, não somente "responde ao que o Outro espera dela, mas, por seu sucesso, satisfaz à demanda além da expectativa. Ela a precede, ela a antecipa em função do seu sucesso, de sua precocidade" (Forget como citado em Bergès-Bounes \& Calmettes-Jean, 2010, p. 79). Essa seria a razão (inconsciente, imagino) de a criança com $\mathrm{AH} / \mathrm{SD}$ não se permitir a falha, de aprender demais?

Calmettes-Jean (citado em Bergès-Bounes \& Calmettes-Jean, 2010, p. 67) retoma esse mesmo mito quando afirma: "quando se duvida de suas próprias capacidades parentais, pode-se ser aliviado de dar o crédito à sua criança de ser autônoma, de se desembaraçar sozinha, de assegurar seu futuro precocemente...". Correlacionando AH/SD e fobia, a autora convoca os adultos a "não jogarem com a dita inteligência das crianças e dar prova de um pouco de seriedade..." porque "como todo mundo... é preciso justamente consentir na 'falta' para que a vida seja possível...”, em lugar de favorecer o que 
ela chama de "eclosão de sintomatologias estruturalmente mal definidas como essa" (Calmettes-Jean como citado em Bergès-Bounes \& Calmettes-Jean, 2010, p. 75).

Entretanto, apesar das "imperfeições" encontradas por seus colegas, Vraive-Douret remete-se a uma pesquisa em desenvolvimento no Grupo Hospitalar Cochin-Port-Royal com 60 "crianças testadas na idade escolar (entre quatro e sete anos de idade) com um QI de pelo menos 130 e que não apresentaram problema particular no seu desenvolvimento antes dos três anos de idade" (Vraive-Douret como citado em Bergès-Bounes \& Calmettes-Jean, 2010 , p. 104). Nessa pesquisa, a autora constatou "uma precocidade de desenvolvimento motor com um avanço médio respectivamente de pelo menos um a dois meses e de um a dois desvios padrão em relação à média" (Vraive-Douret como citado em Bergès-Bounes \& Calmettes-Jean, 2010, p. 104-105), sem estimulação específica.

No plano da linguagem, a autora destaca uma precocidade "paralelamente notável", com aparecimento das primeiras palavras por volta dos 9 meses e a primeira frase por volta dos 18 meses. Ela menciona outros indicadores da precocidade linguística e lógico-matemática, tanto na fala quanto na escrita, da estruturação espacial e temporal e das etapas de desenvolvimento psicoafetivo.

Bastante descontaminada dos preconceitos científicos anteriormente relatados, Vraive-Douret parece reconhecer algumas das características e indicadores que pesquisadores da área já listaram, como elevada receptividade (sensitiva, emocional e afetiva) e intuição; memória, capacidade de raciocínio e tratamento das informações muito desenvolvidos, assim como processos analíticos poderosos; gosto pelo desafio, desgosto por atividades rotineiras, busca de crianças mais velhas ou adultos, senso de humor desenvolvido, senso crítico e autocrítico, generosidade para com os outros, sensibilidade particularà injustiça.

A autora resume a hipótese de que "para essas crianças, esses períodos sensíveis, marcados pelo desejo e pela vontade de agir, parecem mais precoces" e que "isso não prejulga o futuro dessas crianças, toda modelação ou inadequação do ambiente (família, creche, pares) sendo possível" (Vraive-Douret como citado em Bergès-Bounes \& Calmettes-Jean, 2010, p. 109). Como bem afirmava Novaes (1979, p. 49) em seu estudo sobre o desenvolvimento psicológico do superdotado: em geral, tratando-se de crianças superdotadas, sabemos que a falta de oportunidades educacionais, a pobreza de estímulos ambientais, a pressão social para atitudes de conformismo, além das dificuldades da escola de reconhecer e desenvolver suas habilidades e das distorcidas expectativas de pais e professores, dificultam, comumente, o desenvolvimento de suas potencialidades, fato que se acentua ainda mais em crianças provindas de baixo nível socioeconômico.

Apesar de entender que a "inteligência" aferida nos testes não é nada mais que a capacidade de resolver questões lógicas rápida e corretamente e de entender que os escores superiores à média não atestam que alguém será "particularmente sábio, culto, nem mesmo performativo para se adaptar à vida real", ou asseguram que "será apto a fazer boas escolhas, a tomar boas decisões, a se integrar em uma equipe", Vincent (como citado em Bergès-Bounes \& Calmettes-Jean, 2010, p. 131, grifo nosso) afirma que o que parece, "infelizmente, se verificar pelas enquetes feitas sobre crianças superdotadas" é que se a criança "precoce" já tem dificuldades no decorrer de seus estudos, essas dificuldades podem ser ainda piores no mundo do trabalho. As "enquetes" a que Vincent se refere são o impressionante estudo longitudinal com crianças com escores de QI superiores a 140, iniciado por Terman em 1925 e, talvez após alguma comunicação do além com o seu autor (que faleceu em 1956), ela refere que "Terman assegura que, setenta anos depois, os térmitas [...] têm um sucesso bem superior à média" (Vincent citado em Bergès-Bounes \& Calmettes-Jean, 2010, p. 133).

É importante fazer um parêntese para esclarecer que, ao contrário do que se desprende das palavras de Vincent, Terman nada teve a ver com o National Center of Research on Gifted and Talented, um centro de pesquisas que reúne, sim, universidades, escolas e pesquisadores dos Estados Unidos e do Canadá, sediado na Universidade de Connecticut, no Estado do mesmo nome, e subvencionado pela Lei Jacob Javits Gifted and Talented Students Education Act. O estudo longitudinal de Terman foi (e continua sendo) desenvolvido na Universidade de Stanford, na Califórnia, com cerca de 1.500 crianças com QI superior a 140 que continuam sendo acompanhadas na vida adulta e não há informações de que "a enquete sobre o que se tornaram as crianças da primeira 
turma testada por Terman foi estendida a 250 mil crianças" (Vincent como citado em Bergès-Bounes \& Calmettes-Jean, 2010, p. 132). O estudo original foi publicado em cinco volumes, tendo sido o último (1959) concluído por Oden.

Feitos esses esclarecimentos e sem entrar na discussão sobre os resultados desse estudo sobre pessoas com QI elevado, o importante é corroborar o que Vincent afirma: que o QI elevado não era um bom preditivo do sucesso, fato com o qual a maior parte dos pesquisadores da área de AH/SD concorda.

A inexistência dessa perfeição absoluta, que os autores do livro se surpreendem em encontrar nas $\mathrm{PAH} / \mathrm{SD}$, é bem referendada pelo autor que Vincent apoia - Bert (2003): "ele mostra, antes de tudo, que a população das crianças superdotadas está longe de ser homogênea" e que "essas crianças podem ser alegres, dinâmicas e com alto desempenho, elas podem também desenvolver importantes dificuldades de comportamento na escola e fora dela" (Vincent como citado em Bergès-Bounes \& Calmettes-Jean, 2010, p. 134). Talvez considerando isso improvável em crianças com $\mathrm{AH} / \mathrm{SD}$, a autora destaca o que Bert (2003) afirma, que algumas têm poucos amigos ou nenhum, são hipersensíveis, queixam-se do tédio com crianças de sua idade, buscam a companhia de adultos" e que "podem ser sonhadores ou deprimidos, agitados ou de uma lentidão exasperante" (Vincent como citado em Bergès-Bounes \& Calmettes-Jean, 2010, p. 134).

Parece que, sem conseguir diferenciar o que são características ou indicadores próprios das AH/SD de características pessoais ou dificuldades emocionais ou mesmo psicológicas, mas alheias às $\mathrm{AH} / \mathrm{SD}$, a autora insiste em afirmar que "encontramos também crianças muito perturbadas, apresentando sintomas importantes [...] inquietantes [...], distúrbios do sono e angústias noturnas", que "absorvem tudo o que se lhes ensina como esponjas, questionam incessantemente e as respostas não as satisfazem realmente", que "oscilam entre uma atitude provocativa, desajeitada, e uma atitude depressiva" e que "refugiam-se numa atitude altaneira ou na leitura de livros que não assimilam verdadeiramente" (Vincent como citado em Bergès-Bounes \& Calmettes-Jean, 2010, p. 135).

$\mathrm{O}$ mito da prevalência masculina entre os superdotados é plenamente justificado por Vincent, que refere que "as mulheres, mais do que os homens, fazem o sacrifício de sua superioridade intelectual quando chegamà idade adulta" (Vincent como citado em Bergès-Bounes \& Calmettes-Jean, 2010, p. 136) e exemplifica com uma consulta a um "anuário da Mensa", em que verifica que "elas são no entanto muito menos numerosas (uma para cada quatro homens). Eles permanecem todos obstinadamente solteiros" (Vincent como citado em Bergès-Bounes \& Calmettes-Jean, 2010, p. 137).

Cabe aqui destacar, para explicar melhor ao leitor, que a Mensa é "uma sociedade formada por pessoas de alto QI" que nucleia aquelas que "obtiveram escores na faixa dos $2 \%$ superiores da população, comprovado por testes aplicados pela própria Mensa, ou reconhecidos por ela" (Mensa, 2010), que se associam voluntariamente, o que a descaracteriza como um campo de pesquisa científico. $\mathrm{O}$ seu anuário, portanto, também não pode ser base para as grosseiras generalizações de Vincent (como citado em Bergès-Bounes \& Calmettes-Jean, 2010,p.137) de que "os superdotados estão engolfados massivamente nas atividades informáticas" e que é surpreendente o número dos que não declaram atividade profissional "seja porque pensam que essa atividadeé indigna deles e de suas ambições, seja porque eles são realmente desocupados". A autora atribui a "longa e variada lista de atividades extraprofissionais" que constatou entre os membros da Mensa ao "superinvestimento cognitivo [...] devaneio sem objetivo, sem projeto" e finalmente destaca que "as crianças superdotadas são, de saída, sujeitos em sofrimento, que se ferem com um impossível que não lhes permitiu prever uma identidade própria" (Vincent como citado em Bergès-Bounes \& Calmettes-Jean, 2010, p. 138).

Outro Vincent (Hubert, filósofo) ironicamente afirma não discordar que existam superdotados, embora não se considere um deles porque "tenho a compreensão lenta e, depois, pelo pouco que eu me lembre, a medida do meu QI não me situa nessa crista superior dos inteligentes" (Vincent como citado em Bergès-Bounes \& Calmettes-Jean, 2010, p. 181).

Desse capítulo, curiosamente intitulado "Os Superdotados", que discorre sobre Montaigne, Foucault e Kant, autores mais afeitos à sua profissão, resgato uma citação interessante que o filósofo faz de Kant sobre algo que é extremamente óbvio para qualquer pesquisador da área de $\mathrm{AH} / \mathrm{SD}$ e que também descarta a possibilidade da divina perfeição:

se a originalidade exemplar do talento está designada por este nome mítico de gênio, é 
porque aquele que o possui não pode explicar as irrupções ou compreender como chegou a criar sem qualquer aprendizagem (Vincent como citado em Bergès-Bounes \& CalmettesJean, 2010, p. 190).

Seguramente com uma experiência restrita a apenas certo tipo de pais de crianças superdotadas, que criam expectativas muito elevadas para seus filhos e que não foram devidamente orientadas sobre o tema das AH/SD, Gregorius (como citado em Bergès-Bounes \& Calmettes-Jean, 2010, p. 205) refere que "longe de constituir um assunto de vergonha e de desonra, os pais reivindicam o estatuto de superdotada para sua criança". Outros deméritos que ela aponta é que "os critérios de sociabilidade e de criatividade" atribuídos por Bachmann, da Universidade de Hamburgo, "nem sempre são certificáveis nas crianças ditas 'superdotadas"' (Gregorius como citado em Bergès-Bounes \& Calmettes-Jean, 2010, p. 206) e que essa criança "nem sempre está em situação de sucesso escolar". Essa imagem que se tem do aluno com AH/SD como o "bom aluno" é um mito extremamente disseminado na sociedade.

\section{O Dr. Melman: um caso a parte}

É impossível intercalar as observações sobre a entrevista de Bergès-Bounes e Calmettes-Jean ao psiquiatra Charles Melman, colaborador de Lacan e fundador da Associação Internacional Lacaniana, primeiramente publicada no Journal Français de Psychiatrie (2003), do qual ele é editor-chefe, às observações feitas e a fazer sobre os demais autores do livro. É impressionante o arsenal de mitos que aparece disseminado nela. Porém, em se tratando de uma personalidade desse calibre, o desserviço para a educação de alunos com $\mathrm{AH} / \mathrm{SD}$ pode ser mais devastador, se não for analisado com mais cuidado, pelo que decidi dedicar uma seção especial a suas palavras.

Um excelente professor que tive na faculdade dizia para nós, alunos, que evitássemos as citações e que somente as utilizássemos quando não conseguíssemos expressar com as nossas palavras o que o autor queria dizer. Esse é um desses casos e essa é a razão que justifica as transcrições seguintes.

Melman começa expondo com clareza ímpar o mito da "superioridade" social das PAH/
SD e o sentimento de ódio vulgarmente expresso pelas pessoas que desconhecem o tema:

a utilidade social dos superdotados, aparte do fato de que eles têm a faculdade de se reunir em um clube uma vez que se tornam adultos e de trocar entre eles, não se sabe que mensagem nem qual comunicação, aparte dessa vantagem de pertencer a um clube, não se vê muito bem qual é o interesse, propriamente falando, prático dessa promoção (Bergès-Bounes \& Calmettes-Jean como citado em Bergès-Bounes \& Calmettes-Jean, 2010, p. 91).

Segundo esse monumento da psicanálise, somente os prodígios musicais merecem atenção por demonstrarem "uma destreza muscular cenestésica (sic) excepcional, fora do comum, e que escapa às condições ordinárias de aquisição da habilidade motora", embora ele afirme não enxergar sua importância, a não ser pelo deleite que eles poderão dar, algo que "não é essencial para a marcha da cultura e do pensamento" (Bergès-Bounes \& Calmettes-Jean como citado em Bergès-Bounes \& Calmettes-Jean, 2010, p. 91-2, grifo nosso). Essa afirmação que beira a insanidade, tanto pela simplificação da música a uma destreza muscular quanto pela sua desvalorização no desenvolvimento cultural de uma sociedade, é proliferamente complementada por outras não menos espalhafatosas e que, não fosse terem sido reproduzidas no livro sob análise, poderíamos pensar terem vindo de alguém bem menos letrado que o entrevistado.

O respeito ao ser humano e a sua dignidade, princípio presente em qualquer código de ética, presumo, parece não ser uma das prioridades desse senhor, já que afirma, sem o menor pudor:

o chocante é que se pode programar essas crianças como um programa, um disco ou uma máquina.[...] Essas observações não são feitas nem para desencorajar, nem para encorajar os superdotados, mas para destacar que essa inteligência "mecânica" não se dá sem um número de consequências e, se ela está hoje em dia na moda, é por causa da similaridade com a programação de máquinas. É evidente que o superdotado é aquele que está mais adaptado no manejo e no funcionamento das máquinas; no seu caso, não é mais o homem que faz a máquina, mas a máquina que faz o boneco (Bergès-Bounes \& 
Calmettes-Jean como citado em Bergès-Bounes \& Calmettes-Jean, 2010, p. 92).

Continua o ilustre psiquiatra referendandoa afirmação das organizadoras do livro de que os pais das crianças com AH/SD idealizam seus filhos com $\mathrm{AH} / \mathrm{SD}$ e, portanto, produzem essa forma de idiotia (sim, é esse o termo utilizado!):

o sonho parecendo ser o de dar nascimento a um computador. Nosso estilo de criar nossos filhos pode torná-los completamente idiotas ou superdotados, A questão da equivalência se colocando desde já. Será que ser superdotado não é uma forma de idiotia? (Bergès-Bounes \& Calmettes-Jean como citado em Bergès-Bounes \& Calmettes-Jean, 2010, p. 93, grifo nosso).

O psiquiatra não hesita em declarar que a superdotação é uma psicose socialmente aceita e valorizada, e produzida pelos pais, afirmando que ele teve oportunidade de ver "em um casal de universitários, de que maneira eles produziam sua criança como superdotada" (Bergès-Bounes \& Calmettes-Jean como citado em Bergès-Bounes \& Calmettes-Jean, 2010, p. 94).

Outro mito que ainda não tinha sido explicitamente mencionado pelos demais autores é que somente há crianças com AH/SD em escolas particulares, como Melman (Bergès-Bounes \& Calmettes-Jean como citado em Bergès-Bounes \& Calmettes-Jean, 2010, p. 95) aponta: "não são nunca do ensino público, mas do ensino privado". Felizmente a maioria das pesquisas brasileiras sobre $\mathrm{AH} / \mathrm{SD}$ na escola ocorreram em escolas públicas e estão aí para provar, humildemente, a falácia.

Bergès-Bounes e Calmettes-Jean incentivam a fértil "criatividade" do psiquiatra em relação às $\mathrm{AH} / \mathrm{SD}$, questionando-o sobre a revelada imperfeição dessas crianças, perguntando "que tipo de castração é esquivada, em sua opinião, no superdotado quando tudo lhe é possível e que, ao mesmo tempo, ele pode não fazer nada e estar completamente no fracasso?" (Bergès-Bounes \& Calmettes-Jean como citado em Bergès-Bounes \& Calmettes-Jean, 2010, p. 95). Melman, então, responde: "ser superdotado não dá, em caso algum, uma inteligência prática" (Bergès-Bounes \& Calmettes-Jean como citado em Bergès-Bounes \& Calmettes-Jean, 2010, p. 95).
A menos que alteridade tenha um sentido diferente do que eu conheço, o psiquiatra se equivoca quando infere que "existe essa ignorância nos superdotados da questão da alteridade". Melman associa as $\mathrm{AH} / \mathrm{SD}$ ao incesto entre irmãos e irmãs, quando, concordando com as autoras em que "não somente há um esmagamento das gerações, mas, nas gerações antecedentes, elas são ainda as melhores", sugere que "um estudo sistemático do lugar do incesto nessas crianças" (Bergès-Bounes \& Calmettes-Jean como citado em Bergès-Bounes \& Calmettes-Jean, 2010, p. 96) traria surpresas.

Do alto do conhecimento proporcionado pelos dois anos de pesquisa com 20 crianças com QI acima de 130, as autoras se autorizam a generalizar que a realização incestuosa "é uma constante com eles" (Bergès-Bounes \& Calmettes-Jean como citado em Bergès-Bounes \& Calmettes-Jean, 2010, p. 97). Melman corrobora o fato, sugerindo que seria interessante verificar:

[...] se alguém pode se tornar um superdotado em uma relação organizada com os dois membros do casal parental ou se é preciso sistematicamente que isso seja somente com um deles. Eu aposto que é com um deles, e no mesmo golpe se evacua o outro. Eu não acredito que alguém possa se tornar superdotado com os dois pais o atazanando ali nas costas (Bergès-Bounes \& Calmettes-Jean como citado em Bergès-Bounes \& Calmettes-Jean, 2010, p. 97).

De certa forma contradizendo as afirmações de suas colegas que reconhecem que quem tem escores elevados nos testes de QI é "inteligente", Melman afirma que essas crianças não leem nas entrelinhas (que é a definição de inteligência de Lacan - "ler nas entrelinhas"):

[...] não há nessas crianças um pensamento, é simplesmente uma escrita, uma capacidade de manejar uma escrita cifrada, algorítmica, e desenvolver competências mnésicas, mas isso não tem nada a ver com o pensamento ou o impensado. Eu creio que, em realidade, elas não pensam em nada (Bergès-Bounes \& Calmettes-Jean como citado em Bergès-Bounes \& Calmettes-Jean, 2010, p. 99). 
Para finalizar o verdadeiro festival de mitos e incoerências, o psiquiatra resume num só parágrafo todas as suas crenças sobre "as crianças superdotadas" e sua "anormalidade" ao contrapô-las às crianças "normais":

talvez seja mais difícil de compreender como crianças que são normais, que têm relações sociais normais, que brincam com seus companheiros, que fazem arruaça, etc. têm uma aprendizagem rápida, fácil, sem problema, sem teimosia (Bergès-Bounes \& Calmettes-Jean como citado em Bergès-Bounes \& CalmettesJean, 2010, p. 100).

Finalmente, as autoras pedem a seu interlocutor que fale sobre o "objeto a" dessas crianças, sobre a sua "eventual particularidade", porque, como elas afirmam, "são crianças que habitualmente sentem-se entediadas, é também uma constante" (Bergès-Bounes \& Calmettes-Jean como citado em Bergès-Bounes \& Calmettes-Jean, 2010, p. 100). Contradizendo a experiência da grande maioria dos professores de alunos com $\mathrm{AH} / \mathrm{SD}$, que se sentem transbordados pela quantidade e variedade de interesses que essas crianças apresentam, o psiquiatra afirma:

é formidável isto que vocês dizem, porque não há objeto a, não há nada que as excite, que as acenda, que venha lhes fazer cócegas, nada que elas não tenham o sentimento de aproximar se queimando (Bergès-Bounes \& Calmettes-Jean como citado em Bergès-Bounes \& CalmettesJean, 2010, p. 100).

Depois da difícil seleção de alguns trechos desse desvairado depoimento, cabe tentar mostrar agora o que os autores pensaram sobre o tema que aqui mais nos interessa, que é a Educação. Para Melman, "nesses tempos de escolaridade mais magra", os superdotados são "uma tortura e um problema para os professores" (Bergès-Bounes \& Calmettes-Jean como citado em Bergès-Bounes \& Calmettes-Jean, 2010, p. 91).

\section{Querendo falar da escola...}

São poucas as referências mais concretas à escola, exceto pelas associações míticas da criança com AH/SD com a falta de conformidade com o ideal de "bom aluno", o entendimento do tédio como falta de desejo dos pais dos alunos e a afirmação de que não é necessário um atendimento educacional especializado, dentre as mais destacadas. Há, no livro, uma seção menos suculenta intitulada "E a escola?", que, por não ser uma pergunta respondida com os capítulos ali inseridos, complemento com outros trechos a ela relacionados em outras partes do livro.

Lembro, em primeiro lugar, de uma afirmação bastante corriqueira entre psicólogos, que Meljac (como citado em Bergès-Bounes \& Calmettes-Jean, 2010, p. 13) enuncia: "não se poderia designar um 'superdotado' sem ter verificado, anteriormente, se ele corresponde à definição. $\mathrm{O}$ único que pode fazê-lo é, justamente, o psicólogo".

Essa ideia de que o psicólogo é o profissional que detém "a definição" de superdotação e que a identificação das AH/SD, portanto, somente pode ser feita por esses profissionais da saúde é fundamentado pela autora, com a propriedade de quem faz parte de uma clínica que dedica suas atividades a esse tipo de avaliação.

Ora, quando se trata de alunos com AH/ $\mathrm{SD}$, o "laudo" psicológico somente atesta um desempenho superior à média no raciocínio e fluência verbal (área linguística), e/ ou no raciocínio numérico e na apreciação de sequências lógicas (área lógico-matemática), na memória e na capacidade de resolver problemas do cotidiano (Gardner, 2000; Gardner, Kornhaber \& Wake, 2003).

Qual seria o objetivo da identificação para esses autores? Seria algo assim como um "selo de qualidade" que somente determinados "psicólogos" estariam autorizados a atribuir à criança e outros não? Qual seria a finalidade dessa "garantia de correspondência do superdotado à uma definição de superdotação"?

Felizmente, no Brasil, com o advento da inclusão e o paulatino abandono da visão clínica anteriormente predominante na Educação, a legislação educacional tem deixado claro que, na escola, é o professor capacitado quem faz o processo de identificação, não exigindo um "laudo" para garantir o atendimento educacional especializado ao qual os alunos com $\mathrm{AH} / \mathrm{SD}$ têm direito.

$\mathrm{Na}$ Europa, e especificamente no que tange aos alunos com $\mathrm{AH} / \mathrm{SD}$, há também um documento que data de 1994 - a Recomendação n. 1.248 do Parlamento do Conselho Europeu -, transcrito por 
alguma razão ou talvez deixado ali inadvertidamente, que também reafirma o protagonismo do professor na identificação das crianças com AH/SD, quando afirma, entre outras coisas, que:

em atendimento aos programas de formação continuada, os professores devem prever estratégias de identificação das crianças que tenham grandes capacidades ou um talento especial. Todos que se ocupam com crianças (professores, pais, médicos, trabalhadores sociais, ministérios da Educação, etc.) deveriam disporde informações sobre as crianças superdotadas (Committee of Ministers - Council of Europe, 1994, p. 45, grifo nosso).

Sob essa perspectiva, a identificação dos alunos com AH/SD não pretende encontrar o seu QI-essa, sim, prerrogativa exclusiva dos psicólogos. O seu objetivo é revelar, por meio de instrumentos de avaliação aplicados ao aluno, aos seus pais, professores e/ou colegas, complementados pela observação direta dessa pessoa e outras informações, as características e indicadores de $\mathrm{AH} / \mathrm{SD}$, seus interesses e estilos de pensamento e de aprendizagem, de forma a poder elaborar as estratégias pedagógicas adequadas para sua educação, prerrogativa essa exclusiva dos professores.

Calmettes-Jean questiona a necessidade de diferenciação desses alunos: "por que se deve, no discurso contemporâneo, fazer uma classe à parte para as diferenças, diferenciá-las, fazer delas outros?’" (Calmettes-Jean como citado em Bergès-Bounes \& Calmettes-Jean, 2010, p. 64). "Por que essa precocidade, essa pressa? [...] Para que serve esse avanço? [...] Estar dois anos adiantados conta para quem?" (Calmettes-Jean como citado em Bergès-Bounes \& Calmettes-Jean, 2010, p. 66). Argumenta que "essas crianças não podem escapar ao destino comum dos mortais. E o querê-las excepcionais, diferentes da norma, provoca evidentemente a incompreensão ou a paixão" (Calmettes-Jean como citado em BergèsBounes \& Calmettes-Jean, 2010, p. 64).

Essa falsa "democracia", muito comum no discurso ideológico defensor da "igualdade", contradiz os princípios da inclusão estabelecidos na Declaração de Salamanca. Aliás, curiosamente, na página 43 do livro aparecem alguns parágrafos dessa Declaração, cuja orientação principal do Marco de Ação, devolembrar, diz (também na versão francesa)

que l'école devrait accueillir tous les enfants, quelles que soient leurs caractéristiques particulières d'ordre physique, intellectuel, social, affectif, linguistique ou autre. Elle devrait recevoir aussi bien lês enfants handicapés que les surdoués, [...] ainsi que les enfants d'autres groupes défavorisés ou marginalisés ${ }^{3}$ (UNESCO, 1994, p. 6).

Isto é, como diz a famosa frase de Boaventura Santos (2003, p. 458): “temos o direito a sermos iguais quando a diferença nos inferioriza. Temos o direito a sermos diferentes quando a igualdade nos descaracteriza".

Um tema relacionado à escola trazido à baila é o tédio, frequentemente experimentado pela criança com AH/SD pela falta de desafios adequados na escola, que Bergès e Bergés-Bounes (como citado em Bergès-Bounes \& Calmettes-Jean, 2010, p. 29) interpretam como "a marca nelas da ausência de desejo de seus pais para com elas, ou pelo menos, de sua busca desvairada desse desejo". Os autores relatam a mudança de comportamento de um menino de 8 anos que, uma vez informado sobre o seu "resultado brilhante" nos testes de QI pela sua mãe, disse ter tirado "uma placa de chumbo" que tinha sobre seus ombros e que então não se entediava mais. Essa mudança "mágica" que me parece estar mais relacionada ao reconhecimento das $\mathrm{AH} / \mathrm{SD}$ e ao efeito positivo que isso tem na criança, tem para os autores outra explicação:

era, então, na espera virtual em que ele estava em sua vontade de saber o desejo de sua mãe que se situava o tédio, "a placa de chumbo"; é nesse saber que ele não sabia e que ele esperava que sua mãe lhe dissesse que residia a mola de seu desinteresse; ele não estava entendiado (sic), ele não se entediava, ele se entediava, remetendo contra si o ódio que sentia do outro

\footnotetext{
3 Tradução nossa: "que a escola deverá acolher a todas as crianças, quaisquer que sejam as suas características particulares de ordem física, intelectual, social, afetiva, linguística ou outra. Ela deverá receber tanto as crianças com deficiência quanto as superdotadas, [...] assim como as crianças de outros grupos desfavorecidos ou marginalizados".
} 
que não lhe comunicava um saber que não lhe era acessível (Bergès-Bounes \& Calmettes-Jean como citado em Bergès-Bounes \& CalmettesJean, 2010, p. 29).

Sob essa lógica dos autores, a simples "rotulação" das crianças com AH/SD (quem sabe uma avaliação em massa) seria suficiente para combater o tédio e fazer que esses alunos voltassem a ficar comportados e quietos (como as demais crianças) na sala de aula.

Duas entrevistas feitas pelas organizadoras parecem ser os principais destaques da seção sobre a escola: uma ao inspetor acadêmico Jean-Pierre Delaubier, autor de um relatório sobre a escolarização de alunos intelectualmente precoces, realizado entre 2001 e 2002, na França, e outra à coordenadora Geneviève Blaquière, da Unidade Pedagógica de Integração Experimental (semelhante a uma sala de recursos, no nosso sistema educacional), que atende "crianças com alto potencial apresentando dificuldades de adaptação nos cursos escolares regulares" (Bergès-Bounes \& Calmettes-Jean como citado em Bergès-Bounes \& Calmettes-Jean, 2010, p. 227).

Apesar de Bergès-Bounes e Calmettes-Jean afirmar que o primeiro entrevistado "claramente tem autoridade" para falar sobre o tema, o inspetor refere não ser "um especialista na questão", mas responde sobre ela com afirmações muito contundentes. Os problemas de concentração desses alunos - perturbações graves e patológicas - somam-se às dificuldades de comportamento e ao fracasso escolar - na sua opinião, uma consequência direta da superdotação (precocidade):

[...] essas crianças precoces constituem uma das numerosas categorias de alunos que apresentam dificuldades de comportamento - não sei se podemos falar de perturbações graves para eles: são instáveis em classe, por exemplo, entre os casos mais patológicos, e tão mais graves que perturbam a classe [...] Entre todos os fatores que fazem com que um aluno não seja bem-sucedido, destaca-se a precocidade, ou certo tipo de precocidade, já que algumas dessas crianças não têm qualquer dificuldade e são bem integradas (Bergès-Bounes \& Calmettes-Jean como citado em Bergès-Bounes \& CalmettesJean, 2010, pp. 220-221).
Segundo o inspetor, o grupo que elaborou o relatório foi unânime em pensar que essas crianças não deviam ser "isoladas" das demais, principalmente em tempos de "integração" e que "elas têm uma necessidade de uma vida social normal, sentir-se o mais 'normais' possível" (Bergès-Bounes \& Calmettes-Jean como citado em Bergès-Bounes \& Calmettes-Jean, 2010, p. 222). Refere que a equipe não dispunha de uma amostra representativa e, por essa razão, partiram da observação das "crianças problema", dentre as quais constataram (voilà.) poucos casos de crianças superdotadas (o que qualquer pesquisador iniciante da área de $\mathrm{AH} / \mathrm{SD}$ já sabe e reconhece não como "defeitos") e que:

o que essas crianças têm é uma capacidade de memória acima da média, uma rapidez de tratamento da informação, portanto, certos parâmetros gerais de inteligência, mas, já que se olha a personalidade no seu conjunto, esse fator geral não se manifesta em todos os setores da mesma maneira: em alguns domínios, elas são superperformáticas, e em outros, subperformáticas. [...] Pode às vezes ter um handicap, ter uma doença, um QI muito alto e uma dificuldade ou uma falta de gosto por um domínio de conhecimento intelectual: tudo isso na mesma criança (Bergès-Bounes \& Calmettes-Jean como citado em Bergès-Bounes \& Calmettes-Jean, 2010, pp. 222-223).

Para o inspetor e seu grupo, a identidade da criança somente precisa de um nome e um sobrenome, mas não o reconhecimento "de um só de seus traços, só um dominante" (Bergès-Bounes \& Calmettes-Jean como citado em Bergès-Bounes \& Calmettes-Jean, 2010, p. 224). Na contramão da inclusão, para eles, é preciso localizar as dificuldades "de maneira a fazer não a prevenção da precocidade, o que não tem sentido, mas a prevenção das dificuldades que poderiam resultar daî" (Bergès-Bounes \& CalmettesJean como citado em Bergès-Bounes \& CalmettesJean, 2010, p. 224, grifo nosso). Para o inspetor, que atribui à criança com $\mathrm{AH} / \mathrm{SD}$ uma dissociação entre o corpo e a mente, ela deve reconhecer que tem fraquezas "como os coleguinhas; você não é um super-homem e deve trabalhar como os outros, principalmente nos domínios em que não é tão bom, por exemplo, em educação física" (Bergès-Bounes 
\& Calmettes-Jean como citado em Bergès-Bounes \& Calmettes-Jean, 2010, p. 225, grifo nosso).

Segundo o entrevistado, a necessidade de equilíbrio, para esses alunos em que "certas performances intelectuais estão associadas, ao contrário, com dificuldades pesadas em outros domínios: uma incapacidade de escrever, por exemplo" (BergèsBounes \& Calmettes-Jean como citado em BergèsBounes \& Calmettes-Jean, 2010, p. 226), precisa colocar para essas crianças uma compensação: "não é porque estão desajeitadas em seu corpo, que é preciso suprimir a educação física" (Bergès-Bounes $\&$ Calmettes-Jean como citado em Bergès-Bounes \& Calmettes-Jean, 2010, p. 226).

O inspetor escolar desautoriza o professor para a identificação de alunos com $\mathrm{AH} / \mathrm{SD}$, "porque ele não tem competência para aplicar um WISC ou para dar um diagnóstico. [...] É preciso que ele possa dialogar com o psicólogo escolar que toma a direção do problema e vê quais respostas podem ser trazidas" (Bergès-Bounes \& Calmettes-Jean como citado em Bergès-Bounes \& Calmettes-Jean, 2010, p. 227).

Na segunda entrevista, as autoras perguntam à coordenadora da UPI: "dito de outra maneira, vocês as considera como crianças em dificuldades e não como crianças intelectualmente precoces?” (BergèsBounes \& Calmettes-Jean como citado em BergèsBounes \& Calmettes-Jean, 2010, p. 230). De forma muito didática, a coordenadora explica que se trata de crianças que apresentam dificuldades na escolarização para as quais é preciso encontrar uma solução: "entre esses alunos, alguns são intelectualmente precoces. São esses de que se tem conhecimento. Os alunos intelectualmente precoces que não têm dificuldades na escola não são forçosamente registrados" (BergèsBounes \& Calmettes-Jean como citado em BergèsBounes \& Calmettes-Jean, 2010, p. 230).

O depoimento da coordenadora mostra uma realidade que não é diferente nas escolas brasileiras, onde as crianças com $\mathrm{AH} / \mathrm{SD}$ ainda estão excluídas:

alguns tinham sido colocados no fundo da sala, isolados, para não perturbarem as aulas, outros estavam excluídos do sistema escolar, recusando-se a ir à escola, porque as relações com os outros alunos estavam muito conflituosas (Bergès-Bounes \& Calmettes-Jean como citado em Bergès-Bounes \& Calmettes-Jean, 2010, p. 230).
Para os educadores acostumados a trabalhar em sala de recursos, não causa espanto a afirmação da coordenadora de que a sala é um lugar de refúgio para os alunos intelectualmente precoces, que a frequentam nos intervalos, nos horários de recreio ou quando têm horas vagas, ao contrário das autoras, que perguntam: "eles deixam a sala de aula para se refugiar aí?”.

A educadora explica às autoras alguns dos mitos que já foram destacados anteriormente e as dificuldades que os alunos com AH/SD enfrentam, como, por exemplo, quando esses alunos não fazem anotações, não entregam os temas de casa e questionam o interesse por assuntos já tratados e os professores costumam questionar o "alto potencial" e "suspeitam que os pais produziram um superdotado, empurrando a criança para aprender desde sua idade precoce" (Bergès-Bounes \& Calmettes-Jean como citado em Bergès-Bounes \& Calmettes-Jean, 2010 , p. 235). Para os professores, diz a coordenadora, uma criança precoce é "um bom aluno dócil e desejoso de fazer bem, responder o melhor possível ao que lhe é perguntado" (Blaquière, como citado em Bergès-Bounes \& Calmettes-Jean como citado em Bergès-Bounes \& Calmettes-Jean, 2010, p. 235).

Aponta, ainda, outros mitos encontrados, como a vinculação entre alto QI e sucesso e desempenho acadêmico uniforme, as dificuldades de relacionamento ocasionadas não pela $\mathrm{AH} / \mathrm{SD}$, mas pela forma como as demais pessoas percebem essa diferença, e referenda a necessidade de um ambiente favorável para o desenvolvimento das AH/SD. Também comenta a dificuldade com que os professores têm de "suportar" a maneira como essas crianças questionam, porque "sentem sua competência e, portanto sua autoridade, questionadas, tanto mais que certos alunos precoces são verdadeiros especialistas no domínio que lhes interessa" (Bergès-Bounes \& Calmettes-Jean como citado em Bergès-Bounes \& Calmettes-Jean, 2010, p. 235). Talvez na tentativa de esclarecer uma visão educacional que as autoras parecem desconhecer, informa que a missão da Educação "é encarregar-se de todas as crianças, quaisquer que sejam suas dificuldades e mais especialmente os alunos com necessidades educativas particulares, categoria que inclui as crianças precoces" (Bergès-Bounes \& Calmettes-Jean como citado em Bergès-Bounes \& Calmettes-Jean, 2010, p. 236).

Sem perder a oportunidade de reafirmar seus mitos internos, as autoras perguntam à entrevistada: "é então sob o título de crianças em dificuldade 
que elas têm direito a um 'regime de favor', o que é paradoxal, já que, por definição, elas seriam mais contempladas que as outras" (Bergès-Bounes \& Calmettes-Jean como citado em Bergès-Bounes \& Calmettes-Jean, 2010, p. 236), ao que ela responde que "no que lhes concerne, fala-se atualmente em alunos com necessidades educativas específicas ou particulares" (Bergès-Bounes \& Calmettes-Jean como citado em Bergès-Bounes \& Calmettes-Jean, 2010, p. 236).

Outras perguntas realmente exasperantes se seguem: "elas demandam integração? Você pensa que elas desejam mais se integrar do que ter sucesso escolarmente?" (Bergès-Bounes \& Calmettes-Jean como citado em Bergès-Bounes \& Calmettes-Jean, 2010, p. 236), às quais a coordenadora, logicamente, responde de forma afirmativa.

$\mathrm{E}$, finalmente, para responderà pergunta das autoras sobre se os outros na classe não sabem que eles são precoces, a coordenadora explica às autoras algo que elas deveriam saber, mas não sabem - que as crianças com AH/SD têm direito a ter uma identidade própria como tais:

Sim, agora sabem, mas no começo não sabiam de nada. Fica a contradição que elas frequentemente expressaram: eu sou uma criança precoce, eu tenho alguma coisa a reivindicar em nível de um plano de inteligência e, ao mesmo tempo, eu não quero mais dizer, porque eu vou ser 'chata' e vão me rejeitar. É preciso trabalhar ainda sobre esta imagem da criança precoce (Bergès-Bounes \& Calmettes-Jean como citado em Bergès-Bounes \& Calmettes-Jean, 2010, p. 237).

Está fora das fronteiras da minha compreensão a razão do capítulo de Charlemaine estar inserido nessa seção que pretende falar da escola, pois suas reflexões estão centradas, como o título indica, nas "fronteiras da curva de Gauss" e, portanto, discorre sobre os testes de QI e sua variabilidade. Em algum momento, talvez querendo fazer uma ligação com o tema da seção, ele pergunta: "por que suas particularidades e dificuldades [dos superdotados] somente chamaram a atenção tardiamente na história da educação?", compactuando com o sentimento social de pena pelas pessoas deficientes em contraposição ao sentimento de ódio pelas crianças com $\mathrm{AH} / \mathrm{SD}$, que "a noção de esperança que suscita o reconhecimento de uma precocidade intelectual é de outro quilate que a iniludível decepção que pode engendrar o atestado de debilidade" (Charlemaine como citado em Bergès-Bounes \& Calmettes-Jean, 2010, p. 243). Enfim, como o autor não responde à pergunta que lhe suscitou curiosidade, é necessário dizer que o atendimento educacional especializado para crianças com $\mathrm{AH} / \mathrm{SD}$ já era prática comum 2 mil anos antes de Cristo, entre os chineses, os gregos e outros povos, mas, referindo-nos ao último século (o que também não é tão tardio assim), a "atenção tardia" ocorreu principalmente por razões ideológicas, pelos estereótipos, mitos e crenças populares que levaram a acreditar que esses "a-normais" não eram dignos de "pena" como o eram os "a-normais" do outro lado da curva da Gauss e, como toda minoria social, passaram a ser objeto do "estigma" discriminatório que foi mostrado até agora.

Princelle aborda um tema relacionado à Educação, associando fracasso e sucesso escolar a um excesso (por falha de apropriação do saber e por excesso de apropriação do saber) e à noção psiquiátrica de "inibição". Defende, então, que

justamente a esfera intelectual não possui o privilégio da inibição que toca frequentemente a esfera psicomotora, em particular nas crianças ditas precoces: ela entrava no exercício da escrita, por exemplo; ou afeta o corpo de um mau jeito geral... Ela pode igualmente alterar a capacidade de brincar, de estabelecer relações sociais harmoniosas, domínios muitas vezes preservados nos "maus alunos", ao passo que raros nos "superdotados" (Princelle como citado em Bergès-Bounes \& Calmettes-Jean, 2010, p. 246).

Ilustrando suas afirmações com casos patológicos, novamente, de crianças descritas como intelectualmente precoces e superdotadas e crianças com dificuldades de aprendizagem, a autora atribui a ambos a mesma origem: a castração simbólica "que se trataria de contornar por meio dessas duas estratégias do excesso..." (Princelle como citado em Bergès-Bounes \& Calmettes-Jean, 2010, p. 253).

Ficaram algumas afirmações fora da norma que eu já ia esquecendo de comentar. Rapidamente, lembro que Lemmel e Meljac chamam a atenção de que, nas publicações sobre crianças superdotadas, "raramente se faz menção àqueles que acreditam sê-lo e que não o são" (Lemmel \& Meljac como citado 
em Bergès-Bounes \& Calmettes-Jean, 2010, p. 159). Ora seria um pouco absurdo escrever um livro sobre um tema e tratar de algo que nada tem a ver com o tema. Isso não parece muito ilógico, após a leitura de "A cultura dos superdotados", mas, em todo caso, para os pesquisadores da área de $\mathrm{AH} / \mathrm{SD}$ seria uma perda de tempo e algo um tanto incoerente. Em todo caso, os autores se avocam a essa tarefa um tanto quanto desvinculada do foco do livro, de relatar três casos de crianças que não foram identificadas como "superdotados" (ou intelectualmente precoces), talvez para demonstrar que existem crianças que não tem QI elevado.

Há ainda, no livro, um capítulo de Dokhan (como citado em Bergès-Bounes \& Calmettes-Jean, 2010, p. 129) que resume a história do livro de Chaim Potok, O escolbido, para ilustrar o que devemos fazer para que as crianças superdotadas "não se tornem "subdotadas", e uma resenha de Lemmel sobre um livro de Siaud-Facchin, $A$ criança superdotada, ajudá-la a crescer, ajudá-la a vencer.

Finalmente, o posfácio de Meljac utiliza-se do livro de Daniel Arasse, Histórias de pinturas, para reconhecer-se e reconhecer seus colegas psicólogos no anjo Gabriel, autor da anunciação à Maria nas pinturas que o livro descreve. Afirma a autora, sem qualquer remorso pelos seus preconceitos, que,

sob os traços de Gabriel, ele [o psicólogo] transmite a decisão divina (ou genética como se quiser): vossa criança faz parte dos eleitos, membro de um grupo bem particular, aquele que faz correr atualmente tanta tinta, incluído os pesquisadores patenteados, a elite dos "superdotados" (Meljac como citado em Bergès-Bounes \& Calmettes-Jean, 2010, p. 257).

Como não sou psicóloga, talvez não tenha o direito de interpretar essa analogia feita por Meljac, mas é de se lembrar que, nos escritos bíblicos, Gabriel é o santificado mensageiro de Deus e, porisso, admirado e venerado na Cristandade, no Judaísmo e no Islamismo, isto é, na maior parte do mundo. Freud e Lacan explicam?

\section{Consideraçóes para a mudança}

Felizmente o tema das altas habilidades/ superdotação é cada vez mais objeto de pesquisas científicas, o que, de certa forma, tem contribuído para a divulgação e discussão do atendimento educacional para os alunos que apresentam esse comportamento.

No Brasil, a produção científica ainda é bastante tímida, o que tem dado lugar a uma procura muito grande por publicações estrangeiras e a um número crescente de pessoas que, mesmo sem ter uma formação sólida na área, se atrevem a escrever sobre o assunto.

Felizmente, também, o número de pesquisadores conscientes de sua responsabilidade no campo das AH/SD tem crescido e amadurecido muito e acredito que, em breve, a pesquisa em fontes estrangeiras possa ser objeto de uma avaliação mais crítica.

Embora a obrigatoriedade de atendimento educacional especializado aos alunos com AH/SD em todos os níveis, etapas e modalidades já seja uma realidade legal no nosso País, ainda é necessária a sua implementação prática em todas as escolas brasileiras. Isso requer a formação dos docentes que educam esses alunos; dos gestores que devem promover esse atendimento e colocá-lo em prática; dos profissionais da saúde, que muitas vezes são os primeiros para quem são encaminhados; da família e da sociedade, que devem aceitar, reconhecer e valorizar esses meninos e meninas diferentes, sem preconceitos, sem estereótipos, para que possam se tornar adultos com altas habilidades/superdotação em lugar de, como hoje acontece, se esconderem no anonimato porque cresceram em um mundo que, como vimos neste artigo, os patologizava, os estigmatizava e ridicularizava. O direito a essa identidade - de pessoa com altas habilidades/superdotação - não pode ser violado por um punhado de mitos inconscientemente criados para sanar o desconhecimento e apaziguar o medo do diferente.

\section{Referências}

Bergès-Bounes, M., \& Calmette-Jean, S. (2010). A cultura dos superdotados? Porto Alegre: CMC.

Committee of Ministers - Council of Europe. (1994). Parliamentary Assembly Recommendation 1248. Council of Europe.

Gardner, H. (1999). Inteligência: Um conceito reformulado. Rio de Janeiro: Objetiva. 
Gardner, H., Kornhaber, M. L., \& Wake, W. K. (2003). Inteligência: Múltiplas perspectivas. Porto Alegre: Artmed.

Mensa International Limited. (2010). About us. Recuperado em 2 maio 2010, em http://www.mensa.org

Novaes, M. H. (1979). Desenvolvimento psicológico do superdotado. São Paulo: Atlas.

Organisation des Nations Unies pour l'Éducation, la Science et la Culture. (1994). Déclaration de Salamanque et cadre d'action pour les besoins éducatifs spéciaux. Salamanca: Unesco.

Pérez, S. G. (2003). Mitos e crenças sobre as Pessoas com Altas Habilidades: Alguns aspectos que dificultam o seu atendimento. Cadernos de Educação Especial, (22), 45-59.

Santos, B. D. (2003). Reconhecer para libertar: Os caminhos do cosmopolitismo cultural. Rio de Janeiro: Civilização Brasileira.

Sternberg, R. J. (1997). Successful intelligence. New York: Penguin Putnam.

Sternberg, R. J., Grigorenko, E. L., \& Bundy, D. A. (2001). The predictive value of IQ. Merrill-Palmer Quarterly, 47(1), 1-41.

Recebido: 02/06/2010

Received: 06/02/2010

Aprovado: 03/09/2010

Approved: 09/03/2010 